\title{
MULTIPLE REMAGNETIZATIONS OF LOWER PALEOZOIC LIMESTONES FROM THE TACONICS OF VERMONT
}

\author{
Scott Tucker \\ Department of Atmospheric Sciences, University of Washington
}

Dennis V. Kent

Lamont-Doherty Geological Observatory and Department of Geological Sciences, Columbia University

\begin{abstract}
The natural remanent magnetizations in some upper Cambrian and middle Ordovician limestones from the Taconics of Vermont $\left(\sim 44^{\circ} \mathrm{N} 287^{\circ} \mathrm{E}\right)$ are multicomponent and can be attributed to early Paleozoic, late Paleozoic and Cretaceous-early Tertiary remagnetizations. A northwesterly and up magnetization found at 2 sampling localities, characterized by maximum unblocking temperatures of about $350^{\circ} \mathrm{C}$, has directions prior to tilt correction corresponding to Ordovician reference poles for North America and is likely to represent a Taconic remagnetization. A shallow, southerly magnetization found at a third locality, with unblocking temperatures that range to about $500^{\circ} \mathrm{C}$, has directions corresponding to a Permian (Kiaman and Alleghenian) remagnetization. Common to all 3 sampling localities is a low (up to $300^{\circ} \mathrm{C}$ ) unblocking temperature overprint similar in direction to Cretaceous to Paleocene reference poles.
\end{abstract}

\section{Introduction}

The tendency of Paleozoic carbonates of the Appalachians and the interior of North America to be completely remagnetized has been well documented [e.g., review by Van der Voo, 1988]. A late Paleozoic age for the stable secondary magnetization in many of these carbonates is typically inferred on the basis of similarity with known late Carboniferous and Permian (Kiaman) reference directions [e.g., Scotese et al., 1982], with supporting evidence from negative fold tests [Kent, 1979; Chen and Schmidt, 1984]. The remagnetized directions may be of chemical [McCabe et al., 1983] or thermoviscous [Kent, 1985] origin, but in either case there is circumstantial evidence that the remagnetization may be associated with tectonic fluid migration or enhanced heat flow during the late Paleozoic Alleghenian orogeny [Miller and Kent, 1988]. We investigate in this paper the possibility of earlier remagnetization of Appalachian carbonates affected by the Ordovician Taconic Orogeny.

\section{Geology and Sampling}

The structure of the study area in west-central Vermont is a product of the Taconic Orogeny during the Ordovician and is summarized by Stanley and Ratcliffe [1985]. Horizontal compression related to eastward subduction and a collision with an island arc folded the carbonate platform into the Middlebury Synclinorium. Deep-sea sediments from the continental slope and rise were incorporated into the accretionary prism and eventually were obducted onto the folded carbonate platform producing the allochthonous Taconic thrust slices.

Two groups of samples were collected from the Orwell Limestone in the folded carbonate sediments of the

Copyright 1988 by the American Geophysical Union.

Paper number $88 \mathrm{GL} 03424$.

0094-8276/88/88GL-03424\$03.00
Middlebury Synclinorium. The Orwell Limestone is a finegrained limestone dated as Mohawkian (late medial Ordovician) by ostracods, gastropods, and brachiopods [Fisher, 1977]. Orwell-1 samples (14 oriented drill-cores from 2 sites) were taken from an old quarry off Cider Mill Road, near Middlebury. Orwell-2 samples (21 oriented drill cores from 3 sites) were taken from a quarry in Orwell. Each sampling group represents 5 to $10 \mathrm{~m}$ of section in gently dipping (less than $20^{\circ}$ ) beds.

The third group of samples was taken from the Hatch Hill Formation in the Giddingsbrook Slice of the Taconic Allochthon, near Fair Haven. This section of the Hatch Hill Formation consists of black to grey argillite beds with interbeds of dolostone, sandstone, chert breccia, and limestone. Baldwin [1983] has suggested a late Cambrian age for these rocks using lithostratigraphic correlations with the autochthonous shelf sequence. Hatch Hill samples (56 oriented drill-cores from 8 sites) were taken in steeply dipping to overturned beds exposed along the Poultney River.

\section{Paleomagnetic Results}

After the removal of large, spurious magnetizations by $100^{\circ}$ to $200^{\circ} \mathrm{C}$ of thermal demagnetization, the natural remanent magnetization (NRM) of the 3 groups of samples is typically comprised of two components. Common to most of the sample is a dominant northward and steeply down component (labelled A) which is unblocked by $300^{\circ} \mathrm{C}$, at which temperature the NRM is generally reduced to about $10 \%$ or less of its initial $(0.5-1 \mathrm{~mA} / \mathrm{M})$ value (Figure $1 \mathrm{a}, \mathrm{b}$, c). The direction of this component, defined by a least squares fit [Kirschvink, 1980] on 3 or more demagnetization data points from $200^{\circ}$ to $300^{\circ} \mathrm{C}$ for each sample, is very consistent, with an overall mean of Declination/Inclination $=$ $344^{\circ} \%+60^{\circ}$, a95 $=1.9^{\circ}$ for 13 sites (Table 1; Figure $2 \mathrm{a}$ ).

In Orwell-1 samples, the small residual magnetization $(\sim 0.1 \mathrm{~mA} / \mathrm{m})$ is completely unblocked by $350^{\circ} \mathrm{C}$ (Figure $\left.1 \mathrm{a}\right)$. Our best estimate for the direction of this magnetization is based on sample data from the highest demagnetization levels that are distinguishable from measurements of noise, generally between $300^{\circ}$ and $330^{\circ} \mathrm{C}$. Despite the very low magnetization intensities, a consistent northwesterly and shallow component (B1) can be isolated in all 14 of the Orwell-1 samples (Figure $2 \mathrm{~b}$ ), giving a reasonably welldefined mean direction of $313^{\circ} \% 9^{\circ}$, a95 $=7.6^{\circ}$, with little change after correction for the small bedding tilts (Table 1).

In Orwell-2 samples, the remaining magnetization (B2) is usually present over higher demagnetization levels, up to about $400^{\circ} \mathrm{C}$ and sometimes $500^{\circ} \mathrm{C}$ (Figure $1 \mathrm{~b}$ ), but is nevertheless difficult to isolate because of interference from the very dominant A component. What is however unambiguous is that B2 is not northerly, but rather shallow and southerly (Figure 2b). For 15 samples, generally at the $400^{\circ}$ to $450^{\circ} \mathrm{C}$ treatment level, the mean direction for $\mathrm{B} 2$ is $180^{\circ} / 9^{\circ}$, a95 $=6.8^{\circ}$, again with little change after tilt corrections (Table 1 ).

In the Hatch Hill samples, the final magnetization (B3) is 

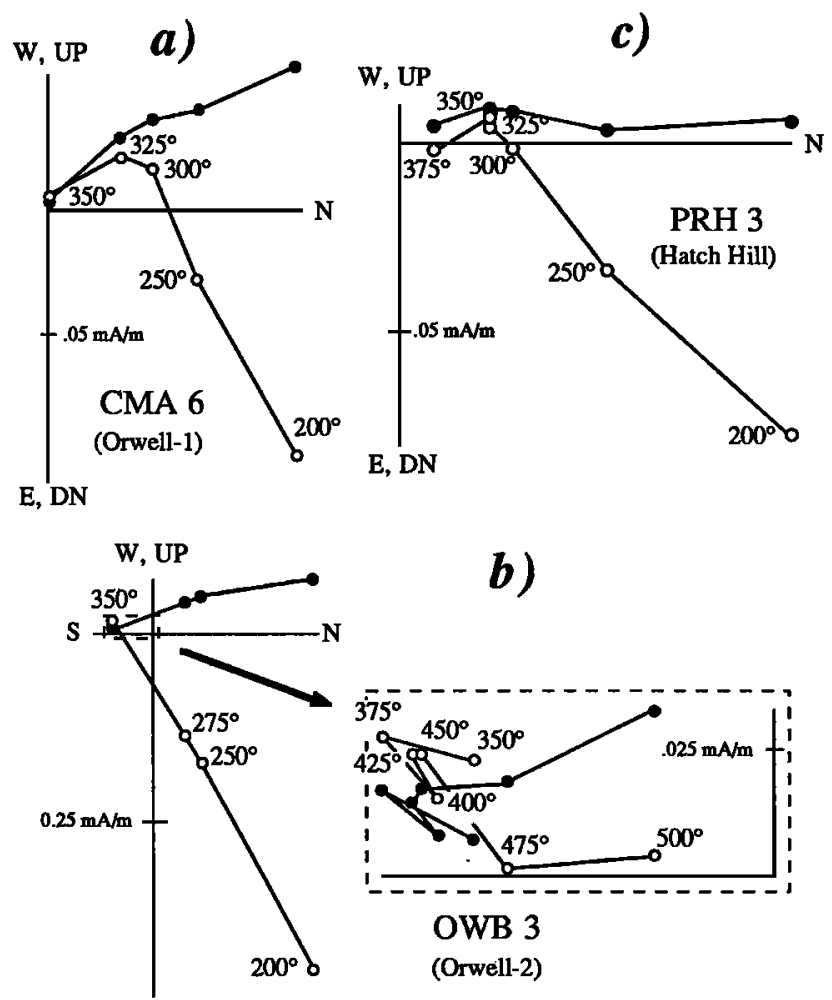

E, DN

Fig 1. Zijderveld demagnetograms of NRM for representative samples from a) Orwell-1, b) Orwell-2, and c) Hatch Hill localities. Open (closed) symbols plotted on vertical (horizontal) planes in geographic coordinates; thermal demagnetization levels in ${ }^{\circ} \mathrm{C}$.

similar to that of Orwell-1: this component is mostly unblocked by $350^{\circ} \mathrm{C}$ (Figure 1c) and has a shallow, northwesterly direction (Figure 2c). Only about half (27) of the Hatch Hill samples provided interpretable data for the final B3 component, the remainder of the samples becoming too weakly magnetized for reliable measurement before the dominant A component could be removed. Giving unit weight to each of the 8 site-means, the mean direction for $\mathrm{B} 3$ is $333^{\circ} \% 2^{\circ}, \mathrm{a} 95=11.0^{\circ}$; after correction for the steep bedding tilts, the direction becomes $10^{\circ} /-29^{\circ}$ with a slight but not significant improvement in grouping (Table 1)
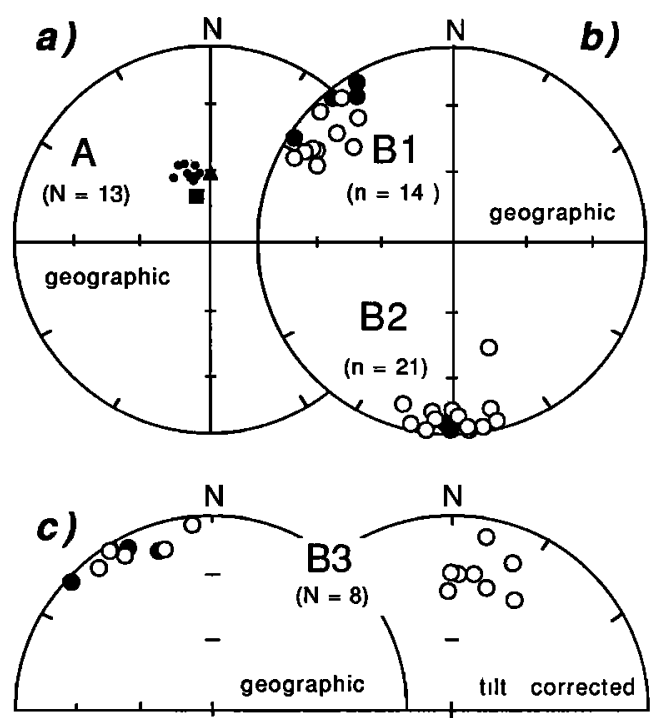

Fig. 2. Component directions from Taconic limestones, with open (closed) symbols plotted on upper (lower) hemispheres of equal-area projections.. a) A component site-mean directions (circles) from Orwell-1, Orwell-2 and Hatch Hill, compared to directions of present Earth's field (square) and dipole field (triangle) for the area. b) B component directions for samples from Orwell-1 (B1) and Orwell-2 (B2). c) B component site-mean directions from Hatch Hill.

\section{Rock Magnetic Constraints}

Good correspondence can be observed between bulk magnetic properties, as deduced from acquisition and thermal demagnetization of isothermal remanent magnetization (IRM), and the NRM characteristics. Applied inductance fields required to achieve half the maximum IRM (at 0.5 Tesla) range from less than 0.05 Tesla (Orwell-2) to about 0.1 Tesla (Hatch Hill). The relatively low maximum IRM values $(\sim 0.1 \mathrm{~A} / \mathrm{M})$ suggest that the total concentration of magnetic carriers is small.

In the unblocking temperature spectra of maximum IRM (Figure 3), all samples tested showed a marked decrease in maximum IRM after only $100^{\circ} \mathrm{C}$ which can be related to the corresponding large component of NRM removed in the initial stages of thermal demagnetization. More relevant is that Orwell-1 and Hatch Hill samples show a concentration of IRM unblocking temperatures at around the $350^{\circ} \mathrm{C}$, essentially the same treatment level that corresponds to the effective demagnetization of the NRM. While a dip in the

Table 1. Magnetization Component Directions and Paleopoles from Taconic Limestones

\begin{tabular}{|c|c|c|c|c|c|c|c|c|c|c|}
\hline & \multirow[b]{2}{*}{$\mathrm{n}(\mathrm{N})$} & \multicolumn{5}{|c|}{ Geographic } & \multicolumn{4}{|c|}{ Tilt Corrected } \\
\hline & & $\mathrm{D} / \mathrm{I}$ & $\mathbf{k}$ & a95 & LA LO & A95 & $\mathrm{D} / \mathrm{I}$ & $\mathbf{k}$ & a95 & LA LO A95 \\
\hline A & $72(\underline{13})$ & $344 /+60$ & 483 & 1.9 & $78 \mathrm{~N} \mathrm{190E}$ & 2.5 & $311 /+17$ & 2 & 34.1 & $44 N$ 172E 29.1 \\
\hline B1 & $\underline{14}(2)$ & $313 /-9$ & 28 & 7.6 & $26 \mathrm{~N} 161 \mathrm{E}$ & 6.0 & $311 /-9$ & 30 & 7.4 & $25 N$ 163E 6.1 \\
\hline B2 & $15(3)$ & $180 /-9$ & 33 & 6.8 & $51 N 108 E$ & 5.5 & $184 /-18$ & 28 & 7.3 & $56 \mathrm{~N} 100 \mathrm{E}$ \\
\hline B3 & $27(\underline{8})$ & $333 /-2$ & 26 & 11.0 & $39 \mathrm{~N} 142 \mathrm{E}$ & 9.6 & $10 /-29$ & 37 & 9.3 & $30 \mathrm{~N} 96 \mathrm{E}$ \\
\hline
\end{tabular}

$\mathrm{n}(\mathrm{N})$ is the number of samples (sites) analyzed for each component, the mean directions based on the underlined quantity. $\mathrm{D} / \mathrm{I}$ is the mean Declination/Inclination, $\mathbf{k}$ is the associated precision parameter and a95 the radius of the $95 \%$ confidence interval. LA LO are the Latitude Longitude, and $\mathrm{A} 95$ is the radius of the $95 \%$ confidence interval, for the mean north paleopole position based on sample or site poles. 


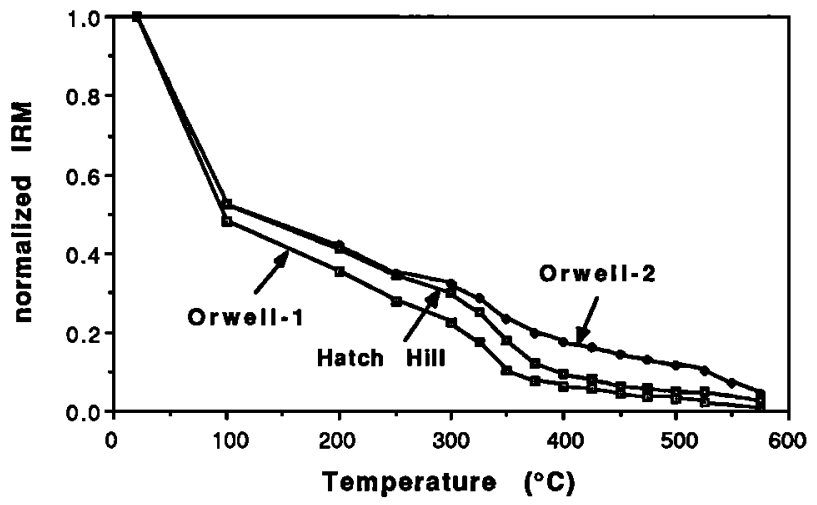

Fig 3. Thermal demagnetization of maximum IRM of representative samples from Orwell-1, Orwell-2 and Hatch Hill sampling localities.

thermal demagnetization curve of IRM at about $350^{\circ} \mathrm{C}$ is also seen in the Orwell-2 samples, more than $25 \%$ of the IRM remains at $375^{\circ} \mathrm{C}$ (compared to less than $10 \%$ in Orwell-1 and Hatch Hill samples) and is not unblocked until about $575^{\circ} \mathrm{C}$; this corresponds to the thermal treatment levels required to demagnetize the NRM of the Orwell-2 rocks.

The high unblocking temperature phase associated with the B2 directions in the Orwell-2 samples is consistent with a magnetite carrier, as observed in other remagnetized limestones in the Appalachians [e.g., Kent, 1979; McCabe et al., 1983]. The identity of the magnetic carrier which has a concentration of unblocking temperatures at around $350^{\circ} \mathrm{C}$ and which is associated with the B1 and B3 magnetizations in the Orwell-1 and Hatch Hill samples is uncertain. A likely candidate is titanomagnetite, whose source may be related to volcanic ash as indicated by the common occurrence of bentonites in many middle Ordovician carbonates in the Appalachians [e.g., Walker, 1973]. Maghemite is unlikely because its inversion to less magnetic hematite is not compatible with the enhanced IRM capacity these limestones possess after heating. Abundant yellowish grains were observed in polished sections under reflected light but these did not attract magnetic colloid and hence are unlikely to be ferrimagnetic pyrrhotite.

\section{Interpretation of Results}

Variability in bedding attitudes was not sufficient within each sampling locality for a statistically diagnostic fold test, therefore the origin of the $\mathrm{B}$ component magnetizations must be inferred indirectly. The B component inclinations are all shallow, consistent with predicted low paleolatitudes for either the early Paleozoic or the late Paleozoic for North America [Van der Voo, 1988]. Component B2 is perhaps the simplest to account for: its reversed polarity direction is similar to Kiaman (late Carboniferous and Permian) overprints documented in many limestones from North America [Miller and Kent, 1988]. Indeed, the paleopole $\left(51^{\circ} \mathrm{N} 108^{\circ} \mathrm{E}\right)$ falls close to the Permian portion of the North American apparent polar wander (APW) path (Figure 4).

Magnetizations $B 1$ and $B 3$ are less expected than $B 2$ in Paleozoic limestones from the Appalachians because they are neither of the appropriate polarity nor direction to correspond to pervasive Permo-Carboniferous remagnetizations. The paleopole for $\mathrm{B} 1\left(26^{\circ} \mathrm{N} 161^{\circ} \mathrm{E}\right)$ from the autochthonous and nearly flat-lying middle Ordovician Orwell Ls. falls between the paleopoles from the lower Ordovician Oneota Dolomite $\left(10^{\circ} \mathrm{N} 166^{\circ} \mathrm{E}\right.$; Jackson and Van der Voo, 1985) and the middle Ordovician Moccasin-Bays Fms. (33 $\mathrm{N} 147^{\circ} \mathrm{E}$; Watts and Van der Voo, 1979) (Figure 4). The interpretation of paleopole B3 from the steeply dipping and allochthonous upper Cambrian Hatch Hill Fm. is less clear: if regarded as a secondary (post-folding) magnetization, the paleopole $\left(39^{\circ} \mathrm{N}\right.$ $142^{\circ} \mathrm{E}$ ) corresponds within the statistical uncertainties to middle Ordovician reference poles (i.e., Moccasin-Bays). If regarded as a pre-Taconic folding magnetization, the tiltcorrected paleopole $\left(30^{\circ} \mathrm{N} 96^{\circ} \mathrm{E}\right)$ is divergent from known late Cambrian (age of rock unit) to Ordovician (age of folding) paleopoles from North America and would imply a large clockwise rotation (Figure 4).

In any case, we conclude that magnetizations B1 and B3 are of early Paleozoic age, most likely remagnetizations associated with the Taconic orogeny. An interesting problem is how these magnetizations survived the remagnetization event in the late Paleozoic that clearly produced the B2 directions in nearby exposures of the Orwell Limestone.

\section{Discussion}

The Conodont Alteration Index (CAI) index for Ordovician limestones in western Vermont is about 5 [Harris et al., 1978], which corresponds to a minimum temperature of $300^{\circ}$ for a maximum duration of 500 my [Rejebian et al., 1987]. The duration of heating due to burial was most likely considerably shorter than this, hence the exposure temperature was higher; a plausible range of heating duration from $10^{7}$ to $10^{8}$ years would correspond to temperatures of $330^{\circ}$ to $310^{\circ} \mathrm{C}$ according to the experimental data of Epstein et al. [1977] and Rejebian et al. [1987].

The paleomagnetic data from Orwell-1 and Hatch Hill samples provide a strong constraint on the maximum temperatures. If we accept that the B1 and B3 components are of early Paleozoic age, then these rocks could not have been exposed even over short durations to temperatures in excess of $350^{\circ} \mathrm{C}$ (the maximum unblocking temperature of this B component) since the middle Ordovician (ca. $460 \mathrm{Ma}$ ), or else the magnetizations would have been destroyed as directly evidenced by the laboratory thermal

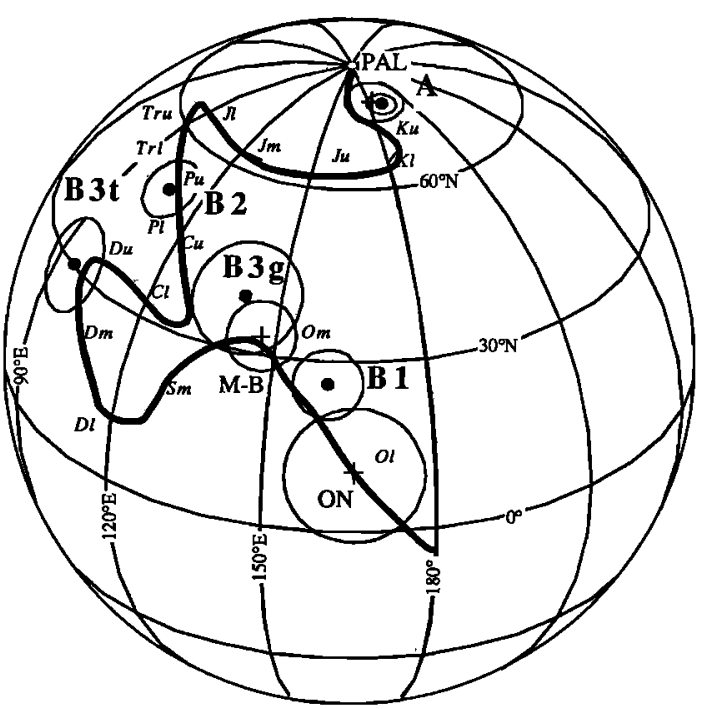

Fig 4. Paleopole positions (solid dots with A95 circles) for mean A, B1, B2 and B3 components from Taconic limestones, compared to lower Ordovician to Recent APW path for North America (dark curve with Ol, etc.) after Van der Voo (1988) and selected North America APW reference poles (crosses with A95 circles) cited in text [lower Ordovician Oneata (ON), middle Ordovician Moccasin-Bays (M-B), and a mean Paleocene (PAL)]. The B3 paleopole is shown before (B3g) and after (B3t) bedding tilt correction; other Taconic paleopoles plotted without tilt correction. 
demagnetizations. On the other hand, the preservation of the B1 and B3 components while exposed to CAI-derived temperatures of around $300^{\circ} \mathrm{C}$ (for about $10^{8} \mathrm{yrs}$ ) is rather remarkable and can be explained theoretically by the nature of (titano)magnetite unblocking close to the Curie point (presumed here to be $350^{\circ} \mathrm{C}$ ), the so-called A region of Pullaiah et al. [1975]. Magnetic unblocking is not a strong function of time in the A region, thus the effects of temperature (e.g., demagnetization) observed in short term, laboratory heating experiments should be nearly equivalent to the effects that occurred at about the same temperature level for geologic time spans. It is therefore possible to reconcile the thermal history constraints from conodont alteration and the paleomagnetic and rock magnetic data if short to long term exposure temperatures are limited to less than about $330^{\circ} \mathrm{C}$ since the middle Ordovician.

The late Paleozoic remagnetization observed only in the Orwell-2 rocks (component B2) can be attributed to a relatively higher concentration of magnetite than is present in the Orwell-1 and Hatch Hill rocks, as revealed in the IRM experiments. Whether this magnetite was present originally or represents a late authigenic phase cannot be ascertained. Evidently the thermoviscous or chemical remanent signature of the late Paleozoic paleomagnetic field overwhelms any early Paleozoic magnetization in the Orwell-2 rocks. It is interesting to note that the older Paleozoic magnetizations (in Orwell-1 and Hatch Hill samples) are associated with magnetic mineralogies which have comparatively lower unblocking temperatures than the Orwell-2 samples which record a younger Paleozoic magnetization.

A remaining question is the origin of the ubiquitous and highly consistent A component found in these rocks. An obvious possibility is that this component represents a recently acquired viscous remanence but the direction $(344 /+60)$ does not actually correspond to either the expected dipole (time-averaged) field $\left(000 \%+62^{\circ}\right)$ nor the present geomagnetic field $\left(345^{\circ} \%+71^{\circ}\right)$ for the locality (Fig 3a). Instead, the A component paleopole $\left(78^{\circ} \mathrm{N} 190^{\circ} \mathrm{E}, \mathrm{A} 95=2.5^{\circ}\right)$ falls close to the Cretaceous and early Tertiary portion of the APW path for North America (Figure 4), for example, within about $1^{\circ}$ of the 55 to $67 \mathrm{Ma}$ (Paleocene) mean pole of $78.7^{\circ} \mathrm{N}$ $185.1^{\circ} \mathrm{E}$ (A95=5 ${ }^{\circ}$; Gordon, 1984). We therefore entertain the possibility that the A component represents a Cretaceous to early Tertiary overprint, perhaps associated with a regional heating event thought to have given rise to an episode of major uplift and erosion in the southeastern Canada-New England region in this time frame [e.g., Crough, 1981]. An ancient origin for the A component can eventually be confirmed or denied by a drumlin test [Kent, 1985].

Acknowledgments. We thank Susan Halgedahl for optical microscopic observations of polished sections, and she and John Miller for critical readings of the manuscript. This work was supported in part by the National Science Foundation, grants EAR85-07046 and EAR88-03814. Lamont-Doherty Geological Observatory contribution 4349.

\section{References}

Baldwin, B., Sedimentation rates of the Taconic sequence and Martinsburg Formation, Am. J. Sci. 283, 178-191, 1983.

Chen, D. L. and V. A. Schmidt, Paleomagnetism of the Middle Mississippian Greenbrier Group in West Virginia, USA, in Plate reconstruction from Paleozoic paleomagnetism, edited by R. Van der Voo, C. R. Scotese and N. Bonhommet, pp.48-62, American Geophysical Union, Washington, D.C., 1984

Crough, S. T., Mesozoic hotspot epeirogeny in eastern North America, Geology, 2, 2-6, 1981.

Epstein, A. G., J. B. Epstein, and L. D. Harris, Conodont
Color Alteration--an Index to Organic Metamorphism, Geological Survey Professional Paper 995, 27 pp., U.S. Government Printing Office, Washington, D.C., 1977.

Fisher, D. W., Correlation of the Hadrynian, Cambrian and Ordovician rocks in New York State, New York State Museum, Map and Chart Series Number 25, 1977.

Gordon, R. G., A Paleocene North American Poles Incorporating Declination-only Data, Geophys. Res. Lett., $11,477-480,1984$.

Harris, A. G., L. D. Harris, and J. B. Epstein, Oil and gas data from Paleozoic rocks in the Appalachian basin, U.S. Geol. Surv. Misc. Investigations Map I-1249, U.S. Geol. Surv., Reston, Va., 1978.

Jackson, M., and R. Van der Voo, A Lower Ordovician paleomagnetic pole from the Oneota Dolomite, Upper Mississippi Valley,J. Geophys. Res., 90, 10449-10461, 1985.

Kent, D. V., Paleomagnetism of the Devonian Onondaga Limestone Revisited, J. Geophys. Res., 84, 3576-3588, 1979.

Kent, D. V., Thermoviscous remagnetization in some Appalachian Limestones, Geophys. Res. Lett., 12, 805808, 1985.

Kirschvink, J. L., the least-squares line and plane and the analysis of paleomagnetic data, Geophys. J. Roy. astr. Soc., 62, 699-718, 1980.

McCabe, C., R. Van der Voo, D. R. Peacor, C. R. Scotese, and $R$. Freeman, Diagenetic magnetite carries ancient yet secondary remanence in some Paleozoic sedimentary carbonates, Geology, 11, 221-223, 1983.

Miller, J. D., and D. V. Kent, Regional trends in the timing of Alleghenian remagnetization in the Appalachians, Geology, 16, 588-591, 1988.

Pullaiah, G., E. Irving, K L. Buchan, and D. J. Dunlop, Magnetization changes caused by burial and uplift, Earth and Planet. Sci. Lett., 28, 133-143, 1975.

Rejebian, V. A., A. G. Harris, and J. S. Heubner, Conodont color and textural alteration: An index to regional metamorphism, contact metamorphism, and hydrothermal alteration, Geol. Soc. America Bull., 99, 471-479, 1987.

Scotese, C. R., R. Van der Voo, and C. McCabe, Paleomagnetism of the Upper Silurian and Lower Devonian carbonates of New York State: evidence for secondary magnetizations residing in magnetite, Phys. Earth Planet. Inter., 30, 385-395, 1982.

Stanley, R., and N. M. Ratcliffe, Tectonic synthesis of the Taconic orogeny in western New England, Geol. Soc. America Bull., 96, 1227-1250, 1985.

Van der Voo, R., Paleomagnetism of continental North America: the craton, its margins, and the Appalachian Belt, in Geophysical Framework of the Continental United States, edited by L. C. Pakiser and W. D. Mooney, Geological Society of America, Boulder, Colorado,in press, 1988.

Walker, K.R., Stratigraphy and environmental sedimentology of Middle Ordovician Black River Group in the type area New York State, N.Y. State Mus. Bull. 419, 1-43.

Watts, D. R., and R. Van der Voo, Paleomagnetic results from the Ordovician Moccasin, Bays, and Chapman Ridge Formations of the Valley and Ridge Province, eastern Tennessee, J. Geophys. Res. 노,, 645-655, 1979.

D.V. Kent, Lamont-Doherty Geological Observatoty, Palisades, NY 10964.

S. Tucker, Dept. Atmos. Sci., University of Washington, Seattle, WA 98195.

(Received July 11, 1988; accepted August 4, 1988.) 